\title{
Preventive and Protective Properties of Zingiber officinale (Ginger) in Diabetes Mellitus, Diabetic Complications, and Associated Lipid and Other Metabolic Disorders: A Brief Review
}

\author{
Yiming Li, Van H. Tran, Colin C. Duke, and Basil D. Roufogalis \\ Faculty of Pharmacy, The University of Sydney, Sydney, NSW 2006, Australia \\ Correspondence should be addressed to Basil D. Roufogalis, basil.roufogalis@sydney.edu.au
}

Received 16 August 2012; Accepted 21 October 2012

Academic Editor: I-Min Liu

Copyright (C) 2012 Yiming Li et al. This is an open access article distributed under the Creative Commons Attribution License, which permits unrestricted use, distribution, and reproduction in any medium, provided the original work is properly cited.

\begin{abstract}
Zingiber officinale (ginger) has been used as herbal medicine to treat various ailments worldwide since antiquity. Recent evidence revealed the potential of ginger for treatment of diabetes mellitus. Data from in vitro, in vivo, and clinical trials has demonstrated the antihyperglycaemic effect of ginger. The mechanisms underlying these actions are associated with insulin release and action, and improved carbohydrate and lipid metabolism. The most active ingredients in ginger are the pungent principles, gingerols, and shogaol. Ginger has shown prominent protective effects on diabetic liver, kidney, eye, and neural system complications. The pharmacokinetics, bioavailability, and the safety issues of ginger are also discussed in this update.
\end{abstract}

\section{Introduction}

The prevalence of diabetes mellitus has reached epidemic proportions and has affected $6.4 \%$ of adults worldwide in 2010 [1, 2]. Diabetes mellitus is characterised by chronic hyperglycemia resulting from impaired insulin action/secretion and is classified into two major categories, type 1 and type 2 [3]. Type 2 diabetes accounts for $>90 \%$ of diabetes and is associated with metabolic disorder of lipid and carbohydrate $[4,5]$. Effective control of hyperglycaemia in diabetic patients is critical for reducing the risk of micro- and macrovascular disease [6-8]. Side effects of the presently available hyperglycaemia agents have impeded their usefulness as antidiabetic agents. This has led to continuous effort to explore effective agents for control of diabetes mellitus.

Ginger (Zingiber officinale, Roscoe Zingiberaceae) is one of the most widely consumed spices worldwide. From its origin in Southeast Asia and its spread to Europe, it has a long history of use as herbal medicine to treat a variety of ailments including vomiting, pain, indigestion, and coldinduced syndromes $[9,10]$. More recently, it was reported that ginger also possessed anti-cancer, anticlotting, antiinflammatory, and analgesic activities [11, 12]. However, there is less emphasis on the effects of ginger in management of metabolic diseases and their complications. We review here the known effects of ginger on diabetes mellitus, and provide an insight into the active constituents and their mechanisms of action. The pharmacokinetics of ginger and the issue of safety are also discussed.

\section{Antihyperglycaemic Effects of Zingiber officinale}

A number of studies have examined the efficacy of ginger in hyperglycaemia control in vitro and in vivo on cell and animal models and in clinical trials. Investigation of the active principles and mechanism of action have also been undertaken.

2.1. Results from Animal Studies. It was reported that oral administration of an ethanolic extract of ginger $(800 \mathrm{mg} / \mathrm{kg})$ significantly decrease fasting blood glucose level after 1 hour treatment in an STZ-type 1 diabetic rat model. The effect peaked after 4 hours, with ginger producing a $24 \%$ to $53 \%$ reduction in blood glucose at doses ranging from 100 to $800 \mathrm{mg} / \mathrm{kg}$ [13]. Another study showed that a single dose of ginger juice prevented 5-hydroxytryptamine-(5-HT-) induced acute hyperglycemia, suggesting the involvement 
of 5-HT receptors in the glycaemic control. In the oral glucose tolerance test, ginger treatment caused a significant decrease of the area under the curve of plasma glucose levels and an increase of the area under the curve for insulin in STZ-diabetic rats [14]. Long-term treatment with ginger not only affected blood glucose levels, but also decreased serum triglyceride and total cholesterol, increased insulin, and effectively prevented body weight, liver, and kidney weight loss in type 1 diabetic animals [14-16].

Type 2 diabetes mellitus is a chronic metabolic disorder associated with low physical activity and high energy intake [17]. A study on high-fat diet-(HFD-) fed rats reported the protective effect of ginger in the development of various parameters of metabolic syndrome, a condition predisposing to a high risk of type 2 diabetes. After treatment with an ethanolic extract of ginger at doses of 100, 200, and $400 \mathrm{mg} / \mathrm{kg}$ for 6 weeks, the marked rises in body weight, serum glucose, insulin, total cholesterol, LDL cholesterol, triglycerides, free fatty acid, and phospholipids induced by high-fat diet significantly reduced [18]. In a nicotinamide and low dose STZ-induced type 2 diabetic rat model, oral administration of ginger powder $(200 \mathrm{mg} / \mathrm{kg})$ alleviated signs of metabolic syndrome, including decrease of blood glucose, total lipid, and an increase in total antioxidant level [19]. In a combined high-fat diet and STZ-induced type 2 diabetic animal model, better glucose tolerance and enhanced serum insulin concentration were observed in ginger-treated diabetic rats [20]. Furthermore, the major pungent component in ginger, [6]-gingerol $(100 \mathrm{mg} / \mathrm{kg} \mathrm{bw})$ significantly decreased fasting blood glucose and improved glucose tolerance in $\mathrm{db} / \mathrm{db}$ type 2 diabetic mice and lowered plasma triglyceride, total cholesterol, free fatty acid, lowdensity lipoprotein, and plasma insulin levels [21].

In normal animals, the effects of ginger were not always consistent. It was reported that a glucose-lowering effect was observed 1 hour after administration of ginger extract [13]. However, a standardised dry ginger ethanol extract (containing $1.9 \mathrm{w} / \mathrm{w}$ of gingerol) formulated in corn oil EV.EXT $33(25,50$ and $100 \mathrm{mg} / \mathrm{kg})$ did not show any effect on blood glucose in normal rats at 3 hours postdose [22]. Furthermore, in rats fed with fresh squeezed ginger juice for 6 weeks, neither blood insulin nor cholesterol and triglyceride were affected [14].

2.2. Results from In Vitro Studies. An in vitro study verified that an ginger ethyl acetate extract stimulated glucose uptake and GLUT4 expression in L6 myotube cell surface, reduced lipid content in $3 \mathrm{~T} 3$ adipocyte, and inhibited protein glycation [23].

Although it is generally accepted that gingerols, the major pungent component in ginger, are the most prominent biologically active components, direct evidence for the action and mechanism of gingerols in improving glucose homeostasis have not been reported until recently. It was found that the moderate polar portion of ginger extract containing mainly gingerols, particularly $(S)$-[6]- and $(S)$-[8]-gingerol, promoted glucose uptake significantly in L6 cultured rat skeletal muscle cells. This action of gingerols was attributed to facilitation of insulin-independent glucose uptake by increasing translocation of glucose transporter GLUT4 to the muscle cell plasma membrane surface, together with small increases in total GLUT4 protein expression [24]. It was also reported that [6]-gingerol promoted glucose uptake in insulin responsive 3T3-L1 adipocytes [25].

2.3. Results from Clinical Trials. Limited clinical studies have been conducted to investigate the potential beneficial effects of ginger in patients. After consuming $3 \mathrm{~g}$ of dry ginger powder in divided dose for 30 days, significant reduction in blood glucose, triglyceride, total cholesterol, LDL, and VLDL cholesterol was observed in diabetic patients [26]. However, in patients with coronary artery disease taking $4 \mathrm{~g}$ of ginger powder for 3 months, neither blood glucose nor lipid was altered [27]. Such discrepancy of results may be attributed to the variation in chemical composition of the administered ginger extracts, depending on the preparation method, product origin, or storage duration [28, 29]. Clearly more clinical studies are required to evaluate the effectiveness and the pattern of effects of ginger in human subjects with diabetes and metabolic disorders.

\section{Mode of Action of Zingiber officinale on Glycaemic Control}

3.1. Ginger Inhibits Enzymes in Carbohydrate Metabolism. The key enzymes controlling carbohydrate metabolism associated with hyperglycaemia and type 2 diabetes are $\alpha$-amylase and $\alpha$-glucosidase. An in vitro enzyme inhibition study was conducted on successive extracts of ginger with hexane, ethyl acetate, methanol, $70 \%$ methanol-water, and water. The ethyl acetate extract showed the highest $\alpha$-glucosidase and $\alpha$ amylase inhibitory activity, with $\mathrm{IC}_{50}$ values of $180 \mathrm{mg} / \mathrm{mL}$ and $980 \mathrm{mg} / \mathrm{mL}$, respectively. No effects were observed in other extracts. The action of ginger against these two enzymes was found to be correlated with the phenolic contents of gingerol and shogaol in these extracts [30]. However, an aqueous extract of Jamaican ginger showed only a slight inhibitory effect on $\alpha$-glucosidase but not $\alpha$-amylase. These results might be related to the low content of the total phenolic compounds in this water extract of ginger [31]. In vivo studies on rats showed that after long-term (8 weeks) feeding with ginger, the activities of pancreatic lipase, amylase, trypsin, and chymotrypsin were significantly increased. On the contrary, following a single-dose treatment of ginger, the activities of these enzymes were lowered in pancreas, while in intestinal mucosa the amylase and sucrase was stimulated [32].

3.2. Ginger Increases Insulin Release and Sensitivity. Diabetes mellitus is characterised by defects in insulin release or/and insulin sensitivity. In the STZ-induced type 1 diabetic rat model, the reduction of blood glucose level was observed to be accompanied by decreased insulin concentration [3335]. Ginger has been shown to modulate insulin release. In vitro, ginger extract augmented insulin release in the INS1 rat pancreatic $\beta$-cell. It is of interest that this effect was 
more prominent in the presence of exogenous serotonin. In vivo, a glucose tolerance test further confirmed that this ginger extract also enhanced plasma insulin levels in conjunction with lowered blood glucose. In arsenic-induced type 2 diabetic rats, [6]-gingerol showed a protective effect on pancreatic $\beta$-cells and restored the plasma insulin level [36]. The mechanism underlying this action of ginger may involve interaction with the $5-\mathrm{HT}_{3}$ receptor [37]. It was found that gingerols and shogaol can act on $5-\mathrm{HT}_{3}$ receptorion channel complex by binding to a modulatory site distinct from the serotonin binding site, with the potency order [6]shogaol $\geq[8]$-gingerol $>[10]$-gingerol $>[6]$-gingerol [38] . The significance of this mechanism remains to be further evaluated.

Ginger promotes glucose clearances in insulin responsive peripheral tissues, which is crucial in maintaining blood glucose homeostasis. Evidence from in vitro studies has demonstrated that ginger extract and its pungent gingerol principles enhanced glucose uptake in cultured L6 rat skeletal muscle cells and 3T3-L1 adipocytes [24, 25, 39].

3.3. Ginger Improves Lipid Profiles. Impaired insulin-stimulated glucose metabolism is a common feature in obese and diabetic subjects. It is well established that insulin resistance in peripheral tissues is tightly associated with elevated circulating lipids and tissue lipid accumulation [40]. The mechanism studies showed that excessive free fatty acid and fatty acid oxidation inhibited glucose transport into peripheral tissues, the first rate-limiting step in glucose metabolism [41-43]. A number of studies have demonstrated that ginger possessed prominent lipid lowering effects, and subsequently increased insulin sensitivity. The antiobese and lipid-lowering effects of ginger tested on various animal models are summarised in Table 1.

Preliminary clinical trials showed that ginger improved lipid profile in diabetic patients [26]. When ginger was used in combination with other herbs, significant physiological changes, including reduction of body weight, skin thickness, waist/hip circumference, were observed accompanied with reduction of serum triglyceride and cholesterol in diabetic and hyperlipidemic patients $[44,45]$.

\section{Protective Potential of Zingiber officinale for Diabetic Complications}

4.1. Protective Effect of Ginger on Liver. In a high-fat dietfed rat model, an ethanolic extract of ginger $(400 \mathrm{mg} / \mathrm{kg})$ effectively reduced triglyceride and cholesterol levels in liver. Molecular studies revealed that liver mRNA and protein expression of low-density lipoprotein (LDL) receptor increased, and 3-hydroxy-3-methylglutaryl coenzyme A (HMG-CoA) reductase protein was downregulated. The mechanistic evidence suggested that the lipid homeostasis effect of ginger was partially due to a decrease in cholesterol biosynthesis and in enhanced hepatic uptake of circulating LDL cholesterol [46]. Moreover, ginger treatment suppressed the gene and protein expression of hepatic inflammation markers, TNF $\alpha$, and IL- 6 and decreased NF- $\kappa$ B activity [47].
Shanmugam et al. reported that in normal and STZinduced diabetic rats fed with a diet containing $1 \%$ and $2 \%$ of ginger powder for 30 days, the blood glucose level in diabetic rats significantly reduced, while normal rats were not affected. Moreover, in diabetic rats treated with ginger, the activities of superoxide dismutase (SOD), catalase (CAT), glutathione peroxidase (GPx) and glutathione reductase (GR), decreased in hepatic and renal tissues, which resulted in an increment of glutathione (GSH) level and a decrease of malondialdehyde (MDA) level. Therefore, the production of reactive oxygen species reduced and resultant oxidative damage to liver and kidney were attenuated. From histological examination, the degeneration of liver central vein, hepatocytes, and sinusoids recovered with the ginger treatment. The pathological alterations in kidney were also improved. The protective effect of ginger was associated with decreased oxidative stress [48]. An in vitro study showed that zingerone, a metabolite from ginger, inhibited lipid peroxidation in rat liver microsomes at high concentrations $(>150 \mu \mathrm{M})[49]$.

4.2. Protective Effects of Ginger on Kidney. An ethanolic ginger extract was reported to reduce blood glucose level and to restore the total carbohydrates, pyruvate, glycogen, and total protein in kidney tissue of STZ-induced diabetic rats [50]. The same group further investigated the renal cytosolic and mitochondrial enzyme activities. The decreased activities of glucose 6-phosphate dehydrogenase (G6PD), succinate dehydrogenase $(\mathrm{SDH})$, malate dehydrogenase $(\mathrm{MDH})$, and glutamate dehydrogenase $(\mathrm{GDH})$ in diabetic rats were recovered after ginger treatment $(200 \mathrm{mg} / \mathrm{kg})$ for 30 days, and the increased lactate dehydrogenase activity was regulated to normal. Histological examination revealed that ginger treatment appeared to regenerate tubules, restore glomeruli, and reduce fatty infiltration [51]. Al-Qattan and his colleagues reported that in STZ-induced diabetic rats injected intraperitoneally with ginger extract for seven weeks, the serum glucose was significantly lowered, and the urine protein reduced to the same level as the normal group. Histological examination clearly revealed that ginger effectively attenuated the progression of structural nephropathy in diabetic rats. Better corpuscular form, capsular wall integrity, and glomerular layout were observed in rats with ginger treatment. More important, less condensation deposits, mesangial fusion, and protein shedding were seen at the renal corpuscle-capsular space region, which indicated that glomeruli perform better than that of the diabetic rat models [52].

4.3. Protective Effect of Ginger on the Central Nervous System. A study of ethanolic ginger extract on STZ-induced diabetic rat showed that ginger possessed neuroprotective effects by accelerating brain antioxidative defence mechanisms and downregulating the malondialdehyde (MDA) level. The marked decreased activities of antioxidant marker enzymes, superoxide dismutase (SOD), catalase (CAT), glutathione peroxidase (GPx), and glutathione reductase (GR) in diabetic rats were augmented on oral administration 


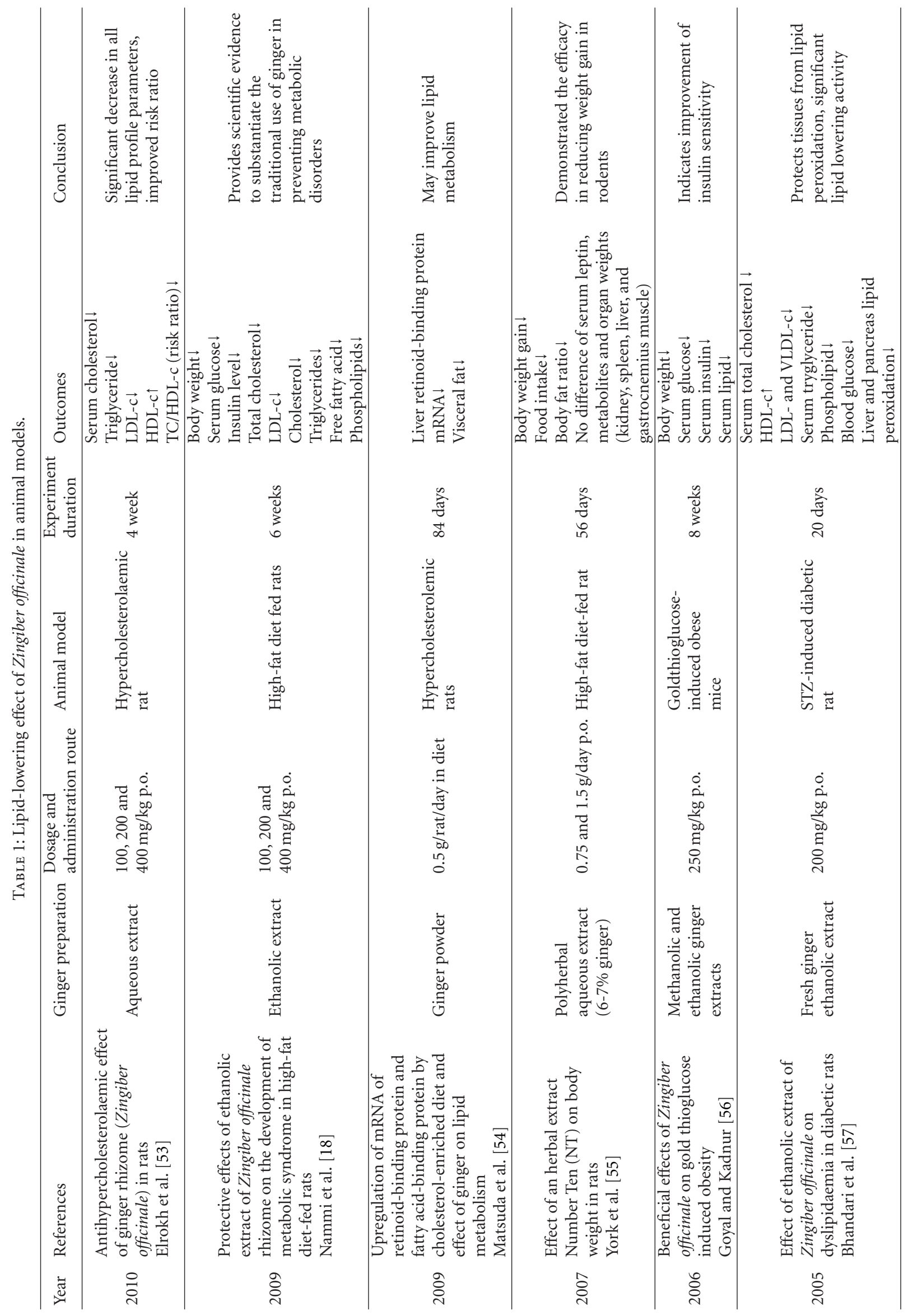




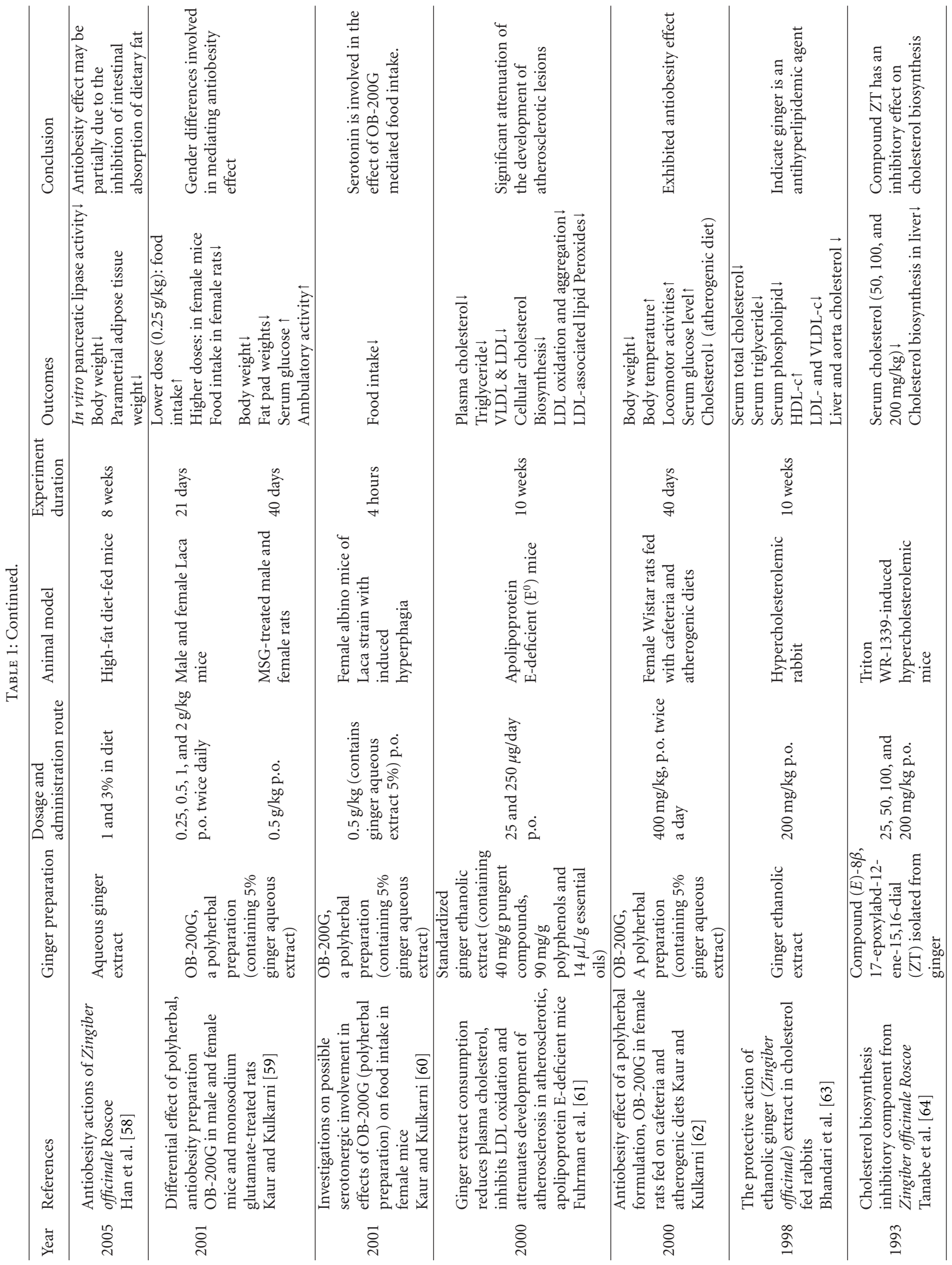


of ginger, hence, resulting in reduction of glutathione and malondialdehyde levels in rat cerebral cortex, cerebellum, hippocampus, and hypothalamus [65].

4.4. Protective Effect of Ginger on the Eye. In the hyperglycemic condition, glucose can be converted to sorbitol and fructose by aldose reductase. Accumulation of polyols results in rapid development of cataract [66]. Compounds isolated from ginger were screened for their aldose reductase inhibitory activities in vitro. 2-(4-Hydroxy3-methoxyphenyl) ethanol and 2-(4-hydroxy-3-methoxyphenyl) ethanoic acid were identified to be of highest potential, with $\mathrm{IC}_{50}$ values of $19.2 \pm 1.9$ and $18.5 \pm 1.1 \mu \mathrm{M}$, respectively. The inhibitory efficiency corresponds to the length of alkyl side chain and presence of the methoxy group on the aromatic ring. Furthermore, these compounds suppressed sorbitol accumulation in human erythrocytes and lens galactitol accumulation in the galactose-fed cataract rat model [67].

Formation of advanced glycation end products (AGE) is accelerated in hyperglycaemic condition, which will lead to the development of diabetic complications. An in vitro test showed that an aqueous extract of ginger at 0.1 and $1.0 \mathrm{mg} / \mathrm{mL}$ reduced CML-KLH and MGO-derived AGE products by $60 \%-80 \%$ and glucose-derived AGE products by $50 \%-60 \%$ [68]. In the STZ-induced diabetic rat model, feeding of ginger significantly inhibited the formation of various AGE products, including carboxymethyl lysine in the lens. Moreover, the progression and onset of cataract were delayed [69].

\section{Pharmacokinetics and Bioavailability of Ginger and Its Major Components}

There is a limited but growing information on the pharmacokinetics and metabolism of ginger and its components. A number of studies revealed that the major components of ginger are excreted as metabolites. After oral administration of a single dose of ginger oleoresin $(300 \mathrm{mg} / \mathrm{kg})$ to rats, 8-gingerol, 10-gingerol, and 6-shogaol were detected in the plasma as the free forms, while the major pungent principle 6-gingerol mainly existed as glucuronide with a Cmax of $3.86 \mu \mathrm{g} / \mathrm{mL}$ and as the free form at $0.93 \mu \mathrm{g} / \mathrm{mL}$ about 1.2 hours after dosing [70]. When 6-gingerol $(50 \mathrm{mg} / \mathrm{kg})$ was given orally to rats alone, approximately $48 \%$ of 6 gingerol was excreted into bile as $(S)$-(6)-gingerol-4 ${ }^{\prime}-O$ $\beta$-glucuronide in 60 hours, and $16 \%$ was excreted into urine as other minor metabolites. In vitro incubation of 6-gingerol with rat liver generated 6-gingerol glucuronide and two other metabolites, [6]-gingerdiol and 9-hydroxy[6]-gingerol [71]. Further studies demonstrated that up to eight metabolites were generated, which indicated a more complex metabolism of [6]-gingerol [72]. Similarly, about $78.5 \%$ of [6]-shogoal was excrete into bile as metabolites over 48 hours after dosing [73]. Another study conducted in rats showed that the pungent components in ginger can be absorbed rapidly. The maximum plasma concentration of [6]-gingerol $(4.24 \mu \mathrm{g} / \mathrm{mL})$ was achieved after 10 minutes after oral dosing of $240 \mathrm{mg} / \mathrm{kg}$ of a ginger extract (containing $53 \%$ of [6]-gingerol) and then declined with time in a biexponential pattern, which could be described as a twocompartment open model. The Cmax of [6]-gingerol was seen in the majority of tissues at 30 minutes; the highest value was $534 \mu \mathrm{g} / \mathrm{g}$ in stomach followed by $294 \mu \mathrm{g} / \mathrm{g}$ in small intestine [74].

In clinical experiments, when human volunteers took $100 \mathrm{mg}$ to $2 \mathrm{~g}$ of ginger extract, there were no free forms of gingerols and shogoal detected in plasma, but these were found as the glucuronide and sulphate conjugates [75]. However, with a more sensitive technique, free forms of 10gingerol and 6-shogoal, as well as glucuronide metabolites of 6-, 8-, and 10-gingerol and 6-shogoal were identified 1 hour after oral dosing with $2 \mathrm{~g}$ of the same ginger extract [76]. It can thus be concluded that gingerols and shogoals are rapidly absorbed in animals and humans and accumulate in a number of tissues and are extensively metabolised in the body.

\section{Safety of Zingiber officinale}

Recently, the safety issue of ginger used as a supplementary medicine has been raised, especially in the specific group of pregnant women using ginger for ease of nausea and vomiting $[77,78]$. Ginger is generally considered safe and is recorded in the US pharmacopeia as a tincture to treat stomach upset. In a randomized double-blinded clinical trial conducted in different countries, women who took $1 \mathrm{~g}$ to $1.5 \mathrm{~g} /$ day of ginger during pregnancy did not show a higher risk of major malformations or other birth defects compared to the general population $[79,80]$. The teratogenic potential of ginger was investigated in pregnant rats. The result showed that oral administration of a standardised ginger ethanolic extract EV.EXT 33 at a dose of $1000 \mathrm{mg} / \mathrm{kg}$ was well tolerated. After 21 days of pregnancy, there was no difference in the number of fetuses, fetal body weight, and sex ratio between ginger treatment group and vehicle control. Furthermore, the number of foetuses with parietal and occipital bone defect decreased in EV.EXT 33 treated rats [81].

The results of toxicological studies showed a broad safety range for ginger usage. The acute toxicity $\left(\mathrm{LD}_{50}\right)$ of methanolic and aqueous ginger extract was 10.25 and $11.75 \mathrm{~g} / \mathrm{kg}$, respectively, by oral administration in mice [82]. When ginger ethanolic extract was administrated intraperitoneally, the $\mathrm{LD}_{50}$ was $1551 \pm 75 \mathrm{mg} / \mathrm{kg}$ in mice [13].

The values of $\mathrm{LD}_{50}$ of the major pungent components in ginger, [6]-gingerol and [6]-shogoal, were 250 and $687 \mathrm{mg} / \mathrm{kg}$ [83]. When ginger is considered for management of components of chronic metabolic syndrome, such as hyperglycaemia or hyperlipidemia, long-term toxicity indeed needs to be investigated. A 35-day toxicity study reported that oral administration of ginger powder up to $2 \mathrm{~g} / \mathrm{kg}$ once daily did not cause any mortality or abnormal changes of the general condition or haematological parameters in either male or female rats. All the biochemical parameters presented normally except for serum lactate dehydrogenase in males. The male rats also showed a slight but significant decrease of testes weight [84]. On the other hand in diabetic 


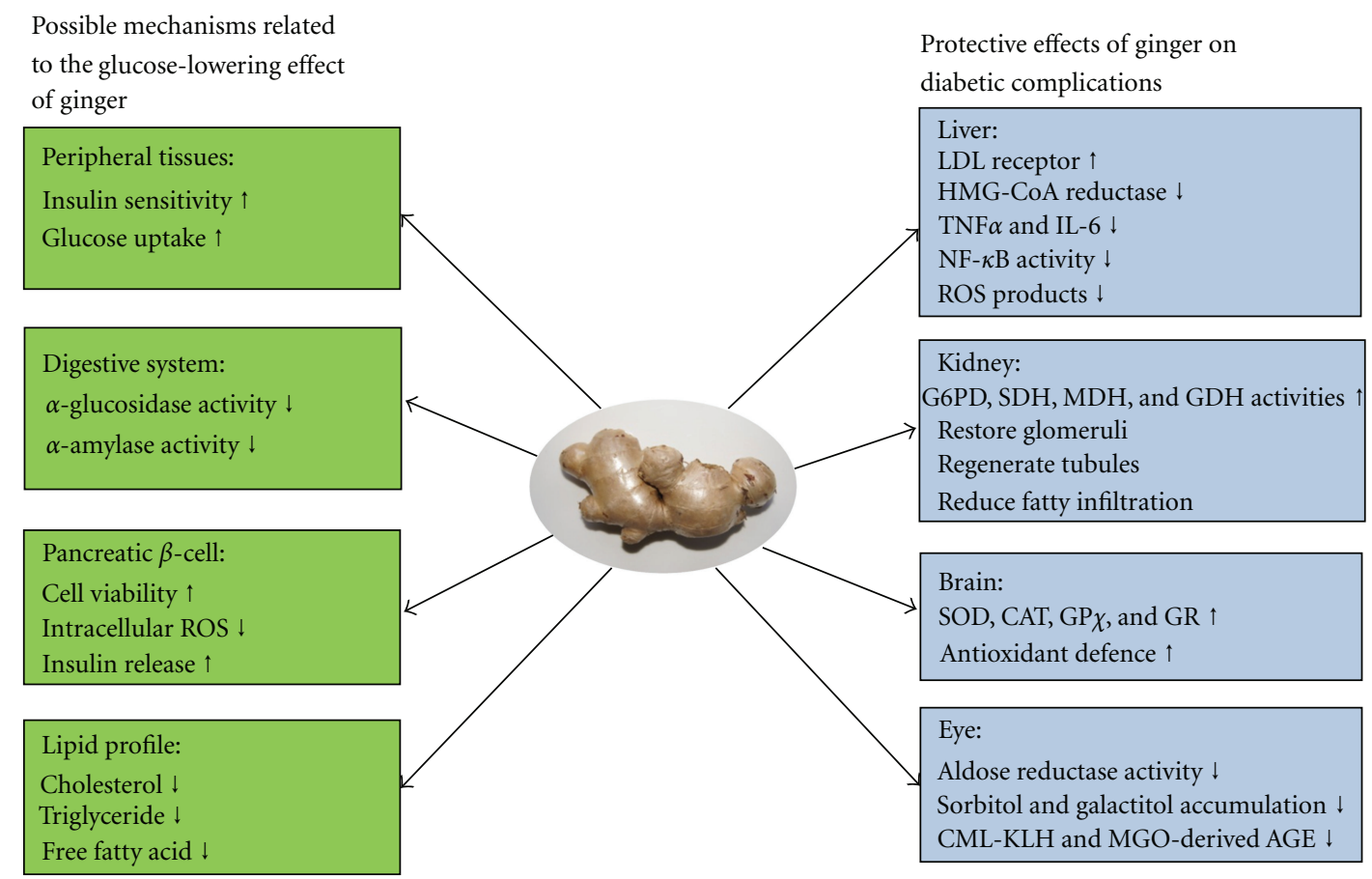

FIGURE 1: Summary of the mechanism of anti-hyperglycaemic and protective effect of ginger.

rats, ginger extract was found to enhance male fertility index and sexual organ weight over a 65 day successive treatment [82].

\section{Summary}

Zingiber officinale (ginger) shows effective glycaemic control properties in diabetes mellitus. The mechanisms underlying these actions are associated with the inhibition of key enzymes controlling carbohydrate metabolism and increased insulin release/sensitivity, resulting in enhanced glucose uptake in peripheral adipose and skeletal muscle tissues. The prominent lipid lowering effects of ginger also contribute to improving the insulin resistant condition. A protective effect of ginger against diabetic complications is also an important aspect of its benefits (Figure 1). Pharmacokinetic and bioavailability studies provide further information for understanding the metabolism of ginger, especially its pungent principles. Sufficient acute and chronic toxicity studies have demonstrated the broad safety of ginger as a complementary hyperglycaemic control agent.

\section{Conflict of Interests}

The authors do not have any conflict of interest with the content of the paper.

\section{Acknowledgment}

This work is supported by an Australian Research Council Linkage Grant.

\section{References}

[1] G. Danaei, M. M. Finucane, Y. Lu et al., "National, regional, and global trends in fasting plasma glucose and diabetes prevalence since 1980: systematic analysis of health examination surveys and epidemiological studies with 370 country-years and 2.7 million participants," The Lancet, vol. 378, no. 9785, pp. 31-40, 2011.

[2] J. E. Shaw, R. A. Sicree, and P. Z. Zimmet, "Global estimates of the prevalence of diabetes for 2010 and 2030," Diabetes Research and Clinical Practice, vol. 87, no. 1, pp. 4-14, 2010.

[3] K. G. M. M. Alberti and P. Z. Zimmet, "Definition, diagnosis and classification of diabetes mellitus and its complications. Part 1: diagnosis and classification of diabetes mellitus. Provisional report of a WHO consultation," Diabetic Medicine, vol. 15, no. 7, pp. 539-553, 1998.

[4] M. Parillo and G. Riccardi, "Diet composition and the risk of type 2 diabetes: epidemiological and clinical evidence," British Journal of Nutrition, vol. 92, no. 1, pp. 7-19, 2004.

[5] "Diagnosis and classification of diabetes mellitus," Diabetes Care, vol. 35, supplement 1, pp. S64-S71, 2012.

[6] K. K. Ray, S. R. K. Seshasai, S. Wijesuriya et al., "Effect of intensive control of glucose on cardiovascular outcomes and death in patients with diabetes mellitus: a meta-analysis of randomised controlled trials," The Lancet, vol. 373, no. 9677, pp. 1765-1772, 2009.

[7] R. R. Holman, S. K. Paul, M. A. Bethel, D. R. Matthews, and H. A. W. Neil, "10-Year follow-up of intensive glucose control in type 2 diabetes," The New England Journal of Medicine, vol. 359, no. 15, pp. 1577-1589, 2008.

[8] F. Ismail-Beigi, T. Craven, M. A. Banerji et al., "Effect of intensive treatment of hyperglycaemia on microvascular outcomes in type 2 diabetes: an analysis of the ACCORD randomised trial," The Lancet, vol. 376, no. 9739, pp. 419-430, 2010. 
[9] B. White, "Ginger: an overview," American Family Physician, vol. 75, no. 11, pp. 1689-1691, 2007.

[10] W. H. Wang and Z. M. Wang, "Studies of commonly used traditional medicine-ginger," Zhongguo Zhongyao Zazhi, vol. 30, no. 20, pp. 1569-1573, 2005.

[11] S. Chrubasik, M. H. Pittler, and B. D. Roufogalis, "Zingiberis rhizoma: a comprehensive review on the ginger effect and efficacy profiles," Phytomedicine, vol. 12, no. 9, pp. 684-701, 2005.

[12] B. H. Ali, G. Blunden, M. O. Tanira, and A. Nemmar, "Some phytochemical, pharmacological and toxicological properties of ginger (Zingiber officinale Roscoe): a review of recent research," Food and Chemical Toxicology, vol. 46, no. 2, pp. 409-420, 2008.

[13] J. A. O. Ojewole, "Analgesic, antiinflammatory and hypoglycaemic effects of ethanol extract of Zingiber officinale (Roscoe) rhizomes (Zingiberaceae) in mice and rats," Phytotherapy Research, vol. 20, no. 9, pp. 764-772, 2006.

[14] S. P. Akhani, S. L. Vishwakarma, and R. K. Goyal, "Antidiabetic activity of Zingiber officinale in streptozotocininduced type I diabetic rats," Journal of Pharmacy and Pharmacology, vol. 56, no. 1, pp. 101-105, 2004.

[15] Z. M. Al-Amin, M. Thomson, K. K. Al-Qattan, and M. Ali, "Anti-diabetic and hypolipidaemic properties of ginger (Zingiber officinale) in streptozotocin-induced diabetic rats," British Journal of Nutrition, vol. 96, no. 4, pp. 660-666, 2006.

[16] N. B. Abdulrazaq, M. M. Cho, N. N. Win, R. Zaman, and M. T. Rahman, "Beneficial effects of ginger (Zingiber officinale) on carbohydrate metabolism in streptozotocin-induced diabetic rats," British Journal of Nutrition, vol. 108, no. 07, pp. 11941201, 2011.

[17] R. H. Eckel, S. M. Grundy, and P. Z. Zimmet, "The metabolic syndrome," The Lancet, vol. 365, no. 9468, pp. 1415-1428, 2005.

[18] S. Nammi, S. Sreemantula, and B. D. Roufogalis, "Protective effects of ethanolic extract of Zingiber officinale rhizome on the development of metabolic syndrome in high-fat diet-fed rats," Basic and Clinical Pharmacology and Toxicology, vol. 104, no. 5, pp. 366-373, 2009.

[19] H. R. Madkor, S. W. Mansour, and G. Ramadan, "Modulatory effects of garlic, ginger, turmeric and their mixture on hyperglycaemia, dyslipidaemia and oxidative stress in streptozotocin-nicotinamide diabetic rats," British Journal of Nutrition, vol. 105, no. 08, pp. 1210-1217, 2010.

[20] M. S. Islam and H. Choi, "Comparative effects of dietary ginger (Zingiber officinale) and garlic (Allium sativum) investigated in a type 2 diabetes model of rats," Journal of Medicinal Food, vol. 11, no. 1, pp. 152-159, 2008.

[21] A. B. Singh, Akanksha, N. Singh, R. Maurya, and A. K. Srivastava, "Anti-hyperglycaemic, lipid lowering and antioxidant properties of [6]-gingerol in $\mathrm{db} / \mathrm{db}$ mice," International Journal of Medicine and Medical Sciences, vol. 1, no. 12, pp. 536-544, 2009.

[22] M. S. Weidner and K. Sigwart, "The safety of a ginger extract in the rat," Journal of Ethnopharmacology, vol. 73, no. 3, pp. 513-520, 2000.

[23] M. P. Rani, M. S. Krishna, K. P. Padmakumari, K. G. Raghu, and A. Sundaresan, "Zingiber officinale extract exhibits antidiabetic potential via modulating glucose uptake, protein glycation and inhibiting adipocyte differentiation: an in vitro study," Journal of the Science of Food and Agriculture, vol. 92, no. 9, pp. 1948-1955, 2012.

[24] Y. Li, V. H. Tran, C. C. Duke, and B. D. Roufogalis, "Gingerols of Zingiber officinale enhance glucose uptake by increasing cell surface GLUT4 in cultured L6 myotubes," Planta Medica, vol. 78, no. 14, pp. 1549-1555, 2012.

[25] K. Sekiya, A. Ohtani, and S. Kusano, "Enhancement of insulin sensitivity in adipocytes by ginger," BioFactors, vol. 22, no. 1-4, pp. 153-156, 2004.

[26] B. Andallu, B. Radhika, and V. Suryakantham, "Effect of aswagandha, ginger and mulberry on hyperglycemia and hyperlipidemia," Plant Foods for Human Nutrition, vol. 58, no. 3, pp. 1-7, 2003.

[27] A. Bordia, S. K. Verma, and K. C. Srivastava, "Effect of ginger (Zingiber officinale Rosc.) and fenugreek (Trigonella foenumgraecum L.) on blood lipids, blood sugar and platelet aggregation in patients with coronary artery disease," Prostaglandins Leukotrienes and Essential Fatty Acids, vol. 56, no. 5, pp. 379384, 1997.

[28] S. D. Jolad, R. C. Lantz, J. C. Guan, R. B. Bates, and B. N. Timmermann, "Commercially processed dry ginger (Zingiber officinale): composition and effects on LPS-stimulated $\mathrm{PGE}_{2}$ production," Phytochemistry, vol. 66, no. 13, pp. 1614-1635, 2005.

[29] S. D. Jolad, R. C. Lantz, A. M. Solyom, G. J. Chen, R. B. Bates, and B. N. Timmermann, "Fresh organically grown ginger (Zingiber officinale): composition and effects on LPS-induced $\mathrm{PGE}_{2}$ production," Phytochemistry, vol. 65, no. 13, pp. 19371954, 2004.

[30] M. Priya Rani, K. P. Padmakumari, B. Sankarikutty, O. Lijo Cherian, V. M. Nisha, and K. G. Raghu, "Inhibitory potential of ginger extracts against enzymes linked to type 2 diabetes, inflammation and induced oxidative stress," International Journal of Food Sciences and Nutrition, vol. 62, no. 2, pp. 106110, 2011.

[31] L. G. Ranilla, Y. I. Kwon, E. Apostolidis, and K. Shetty, "Phenolic compounds, antioxidant activity and in vitro inhibitory potential against key enzymes relevant for hyperglycemia and hypertension of commonly used medicinal plants, herbs and spices in Latin America," Bioresource Technology, vol. 101, no. 12, pp. 4676-4689, 2010.

[32] K. Platel and K. Srinivasan, "Influence of dietary spices and their active principles on pancreatic digestive enzymes in albino rats," Die Nahrung, vol. 44, no. 1, pp. 42-46, 2000.

[33] A. A. Rossini, A. A. Like, and W. L. Chick, "Studies of streptozotocin induced insulitis and diabetes," Proceedings of the National Academy of Sciences of the United States of America, vol. 74, no. 6, pp. 2485-2489, 1977.

[34] A. A. Like and A. A. Rossini, "Streptozotocin induced pancreatic insulitis: new model of diabetes mellitus," Science, vol. 193, no. 4251, pp. 415-417, 1976.

[35] A. Junod, A. E. Lambert, W. Stauffacher, and A. E. Renold, "Diabetogenic action of streptozotocin: relationship of dose to metabolic response," The Journal of Clinical Investigation, vol. 48, no. 11, pp. 2129-2139, 1969.

[36] D. Chakraborty, A. Mukherjee, S. Sikdar, A. Paul, S. Ghosh, and A. R. Khuda-Bukhsh, "[6]-Gingerol isolated from ginger attenuates sodium arsenite induced oxidative stress and plays a corrective role in improving insulin signaling in mice," Toxicology Letters, vol. 210, no. 1, pp. 34-43, 2012.

[37] K. Heimes, B. Feistel, and E. J. Verspohl, "Impact of the 5-HT3 receptor channel system for insulin secretion and interaction of ginger extracts," European Journal of Pharmacology, vol. 624, no. 1-3, pp. 58-65, 2009.

[38] H. Abdel-Aziz, T. Windeck, M. Ploch, and E. J. Verspohl, "Mode of action of gingerols and shogaols on 5-HT3 receptors: binding studies, cation uptake by the receptor channel 
and contraction of isolated guinea-pig ileum," European Journal of Pharmacology, vol. 530, no. 1-2, pp. 136-143, 2006.

[39] K. Noipha, S. Ratanachaiyavong, and P. Ninla-aesong, "Enhancement of glucose transport by selected plant foods in muscle cell line L6," Diabetes Research and Clinical Practice, vol. 89, no. 2, pp. e22-e26, 2010.

[40] J. Denis McGarry, "Dysregulation of fatty acid metabolism in the etiology of type 2 diabetes," Diabetes, vol. 51, no. 1, pp. 7-18, 2002.

[41] P. J. Randle, P. B. Garland, C. N. Hales, and E. A. Newsholme, "The glucose fatty-acid cycle. Its role in insulin sensitivity and the metabolic disturbances of diabetes mellitus," The Lancet, vol. 281, no. 7285, pp. 785-789, 1963.

[42] M. Roden, T. B. Price, G. Perseghin et al., "Mechanism of free fatty acid-induced insulin resistance in humans," The Journal of Clinical Investigation, vol. 97, no. 12, pp. 2859-2865, 1996.

[43] R. I. Fink, P. Wallace, G. Brechtel, and J. M. Olefsky, "Evidence that glucose transport is rate-limiting for in vivo glucose uptake," Metabolism, vol. 41, no. 8, pp. 897-902, 1992.

[44] P. Paranjpe, P. Patki, and B. Patwardhan, "Ayurvedic treatment of obesity: a randomised double-blind, placebo-controlled clinical trial," Journal of Ethnopharmacology, vol. 29, no. 1, pp. $1-11,1990$.

[45] R. Kamal and S. Aleem, "Clinical evaluation of the efficacy of a combination of zanjabeel (Zingiber officinale) and amla (Emblica officinalis) in hyperlipidaemia," Indian Journal of Traditional Knowledge, vol. 8, no. 3, pp. 413-416, 2009.

[46] S. Nammi, M. S. Kim, N. S. Gavande, G. Q. Li, and B. D. Roufogalis, "Regulation of low-density lipoprotein receptor and 3-hydroxy-3- methylglutaryl coenzyme A reductase expression by Zingiber officinale in the liver of high-fat dietfed rats," Basic and Clinical Pharmacology and Toxicology, vol. 106, no. 5, pp. 389-395, 2010.

[47] X.-H. Li, K. C.-Y. McGrath, S. Nammi, A. K. Heather, and B. D. Roufogalis, "Attenuation of liver pro-inflammatory responses by Zingiber officinale via inhibition of NF-kappa B activation in high-fat diet-fed rats," Basic and Clinical Pharmacology and Toxicology, vol. 110, no. 3, pp. 238-244, 2012.

[48] K. R. Shanmugam, K. Mallikarjuna, K. Nishanth, C. H. Kuo, and K. S. Reddy, "Protective effect of dietary ginger on antioxidant enzymes and oxidative damage in experimental diabetic rat tissues," Food Chemistry, vol. 124, no. 4, pp. 14361442, 2011.

[49] A. C. P. Reddy and B. R. Lokesh, "Studies on spice principles as antioxidants in the inhibition of lipid peroxidation of rat liver microsomes," Molecular and Cellular Biochemistry, vol. 111, no. 1-2, pp. 117-124, 1992.

[50] K. R. Shanmugam, C. H. Ramakrishna, K. Mallikarjuna, and K. S. Reddy, "The impact of ginger on kidney carbohydrate metabolic profiles in STZ induced diabetic rats," Asian Journal of Experimental Sciences, vol. 23, no. 1, pp. 127-134, 2009.

[51] S. K. Ramudu, M. Korivi, N. Kesireddy et al., "Nephroprotective effects of a ginger extract on cytosolic and mitochondrial enzymes against streptozotocin (STZ)-induced diabetic complications in rats," The Chinese Journal of Physiology, vol. 54, no. 2, 2011.

[52] K. Al-Qattan, M. Thomson, and M. Ali, "Garlic (Allium sativum) and ginger (Zingiber officinale) attenuate structural nephropathy progression in streptozotocin-induced diabetic rats," e-SPEN, vol. 3, no. 2, pp. e62-e71, 2008.

[53] E. S. M. Elrokh, N. A. Z. Yassin, S. M. A. El-Shenawy, and B. M. M. Ibrahim, "Antihypercholesterolaemic effect of ginger rhizome (Zingiber officinale) in rats," Inflammopharmacology, vol. 18, no. 6, pp. 309-315, 2010.

[54] A. Matsuda, Z. Wang, S. Takahashi, T. Tokuda, N. Miura, and J. Hasegawa, "Upregulation of mRNA of retinoid binding protein and fatty acid binding protein by cholesterol enricheddiet and effect of ginger on lipid metabolism," Life Sciences, vol. 84, no. 25-26, pp. 903-907, 2009.

[55] D. A. York, S. Thomas, F. L. Greenway, Z. Liu, and J. C. Rood, "Effect of an herbal extract Number Ten (NT) on body weight in rats," Chinese Medicine, vol. 2, article 10, 2007.

[56] R. K. Goyal and S. V. Kadnur, "Beneficial effects of Zingiber officinale on goldthioglucose induced obesity," Fitoterapia, vol. 77, no. 3, pp. 160-163, 2006.

[57] U. Bhandari, R. Kanojia, and K. K. Pillai, "Effect of ethanolic extract of Zingiber officinale on dyslipidaemia in diabetic rats," Journal of Ethnopharmacology, vol. 97, no. 2, pp. 227-230, 2005.

[58] L. K. Han, X. J. Gong, S. Kawano, M. Saito, Y. Kimura, and H. Okuda, "Antiobesity actions of Zingiber officinale Roscoe," Yakugaku Zasshi, vol. 125, no. 2, pp. 213-217, 2005.

[59] G. Kaur and S. K. Kulkarni, "Differential effect of polyherbal, antiobesity preparation, OB-200G in male and female mice and monosodium glutamate-treated rats," Indian Journal of Experimental Biology, vol. 39, no. 6, pp. 551-557, 2001.

[60] G. Kaur and S. K. Kulkarni, "Investigations on possible serotonergic involvement in effects of OB-200G (polyherbal preparation) on food intake in female mice," European Journal of Nutrition, vol. 40, no. 3, pp. 127-133, 2001.

[61] B. Fuhrman, M. Rosenblat, T. Hayek, R. Coleman, and M. Aviram, "Ginger extract consumption reduces plasma cholesterol, inhibits LDL oxidation and attenuates development of atherosclerosis in atherosclerotic, apolipoprotein E-deficient mice," Journal of Nutrition, vol. 130, no. 5, pp. 1124-1131, 2000.

[62] G. Kaur and S. K. Kulkarni, "Antiobesity effect of a polyherbal formulation, OB-200G in female rats fed on cafeteria and atherogenic diets," Indian Journal of Pharmacology, vol. 32, no. 5, pp. 294-299, 2000.

[63] U. Bhandari, J. N. Sharma, and R. Zafar, "The protective action of ethanolic ginger (Zingiber officinale) extract in cholesterol fed rabbits," Journal of Ethnopharmacology, vol. 61, no. 2, pp. 167-171, 1998.

[64] M. Tanabe, Y. D. Chen, K. Saito, and Y. Kano, "Cholesterol biosynthesis inhibitory component from Zingiber officinale Roscoe," Chemical and Pharmaceutical Bulletin, vol. 41, no. 4, pp. 710-713, 1993.

[65] K. R. Shanmugam, K. Mallikarjuna, N. Kesireddy, and K. Sathyavelu Reddy, "Neuroprotective effect of ginger on antioxidant enzymes in streptozotocin-induced diabetic rats," Food and Chemical Toxicology, vol. 49, no. 4, pp. 893-897, 2011.

[66] A. Pollreisz and U. Schmidt-Erfurth, "Diabetic cataractpathogenesis, epidemiology and treatment," Journal of Ophthalmology, vol. 2010, Article ID 608751, 8 pages, 2010.

[67] A. Kato, Y. Higuchi, H. Goto et al., "Inhibitory effects of Zingiber officinale roscoe derived components on aldose reductase activity in vitro and in vivo," Journal of Agricultural and Food Chemistry, vol. 54, no. 18, pp. 6640-6644, 2006.

[68] M. Saraswat, P. Y. Reddy, P. Muthenna, and G. B. Reddy, "Prevention of non-enzymic glycation of proteins by dietary agents: prospects for alleviating diabetic complications," British Journal of Nutrition, vol. 101, no. 11, pp. 1714-1721, 2009. 
[69] M. Saraswat, P. Suryanarayana, P. Y. Reddy, M. A. Patil, N. Balakrishna, and G. B. Reddy, "Antiglycating potential of Zingiber officinalis and delay of diabetic cataract in rats," Molecular Vision, vol. 16, pp. 1525-1537, 2010.

[70] W. Wang, C. Y. Li, X. D. Wen, P. Li, and L. W. Qi, "Simultaneous determination of 6-gingerol, 8-gingerol, 10-gingerol and 6-shogaol in rat plasma by liquid chromatography-mass spectrometry: application to pharmacokinetics," Journal of Chromatography B, vol. 877, no. 8-9, pp. 671-679, 2009.

[71] T. Nakazawa and K. Ohsawa, "Metabolism of [6]-gingerol in rats," Life Sciences, vol. 70, no. 18, pp. 2165-2175, 2002.

[72] E. Pfeiffer, F. F. Heuschmid, S. Kranz, and M. Metzler, "Microsomal hydroxylation and glucuronidation of [6]-gingerol," Journal of Agricultural and Food Chemistry, vol. 54, no. 23, pp. 8769-8774, 2006.

[73] A. Asami, T. Shimada, Y. Mizuhara et al., "Pharmacokinetics of [6]-shogaol, a pungent ingredient of Zingiber officinale Roscoe (Part I)," Journal of Natural Medicines, vol. 64, no. 3, pp. 281287, 2010.

[74] S. Z. Jiang, N. S. Wang, and S. Q. Mi, "Plasma pharmacokinetics and tissue distribution of [6]-gingerol in rats," Biopharmaceutics and Drug Disposition, vol. 29, no. 9, pp. 529537, 2008.

[75] S. M. Zick, Z. Djuric, M. T. Ruffin et al., "Pharmacokinetics of 6-gingerol, 8-gingerol, 10-gingerol, and 6-shogaol and conjugate metabolites in healthyhuman subjects," Cancer Epidemiology Biomarkers and Prevention, vol. 17, no. 8, pp. 1930-1936, 2008

[76] Y. Yu, S. Zick, X. Li, P. Zou, B. Wright, and D. Sun, "Examination of the pharmacokinetics of active ingredients of ginger in humans," BMC Biology, vol. 13, no. 3, pp. 417-426, 2011.

[77] D. Tiran, "Nausea and vomiting in pregnancy: safety and efficacy of self-administered complementary therapies," Complementary Therapies in Nursing and Midwifery, vol. 8, no. 4, pp. 191-196, 2002.

[78] Evira Warning label to be added on food supplements containing ginger as well as on ginger tea, and corresponding drink powders, 2012, http://www.evira.fi/portal/en/food/manufacture_and sales/labelling/warning_labelling_and_instructions_for_use/ warning_label_to_be_added_on_food_supplements_containing_ginger_as_well_as_on_ginger_tea__and_corresponding_drink_powders.

[79] F. Borrelli, R. Capasso, G. Aviello, M. H. Pittler, and A. A. Izzo, "Effectiveness and safety of ginger in the treatment of pregnancy-induced nausea and vomiting," Obstetrics and Gynecology, vol. 105, no. 4, pp. 849-856, 2005.

[80] G. Portnoi, L. A. Chng, L. Karimi-Tabesh, G. Koren, M. P. Tan, and A. Einarson, "Prospective comparative study of the safety and effectiveness of ginger for the treatment of nausea and vomiting in pregnancy," American Journal of Obstetrics and Gynecology, vol. 189, no. 5, pp. 1374-1377, 2003.

[81] M. S. Weidner and K. Sigwart, "Investigation of the teratogenic potential of a Zingiber officinale extract in the rat," Reproductive Toxicology, vol. 15, no. 1, pp. 75-80, 2001.

[82] M. A. Shalaby and A. R. Hamowieh, "Safety and efficacy of Zingiber officinale roots on fertility of male diabetic rats," Food and Chemical Toxicology, vol. 48, no. 10, pp. 2920-2924, 2010.

[83] M. Suekawa, A. Ishige, and K. Yuasa, "Pharmacological studies on ginger. I. Pharmacological actions of pungent constituents, (6)-gingerol and (6)-shogaol," Journal of Pharmacobio-Dynamics, vol. 7, no. 11, pp. 836-848, 1984.
[84] X. Rong, G. Peng, T. Suzuki, Q. Yang, J. Yamahara, and Y. Li, "A 35-day gavage safety assessment of ginger in rats," Regulatory Toxicology and Pharmacology, vol. 54, no. 2, pp. 118-123, 2009. 


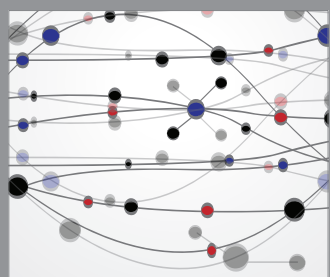

The Scientific World Journal
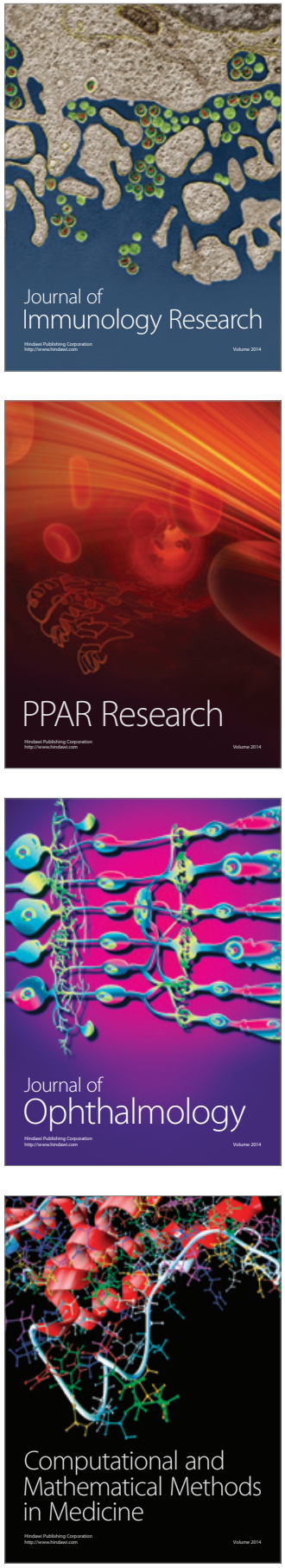

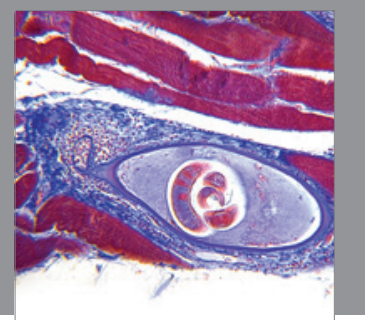

Gastroenterology

Research and Practice
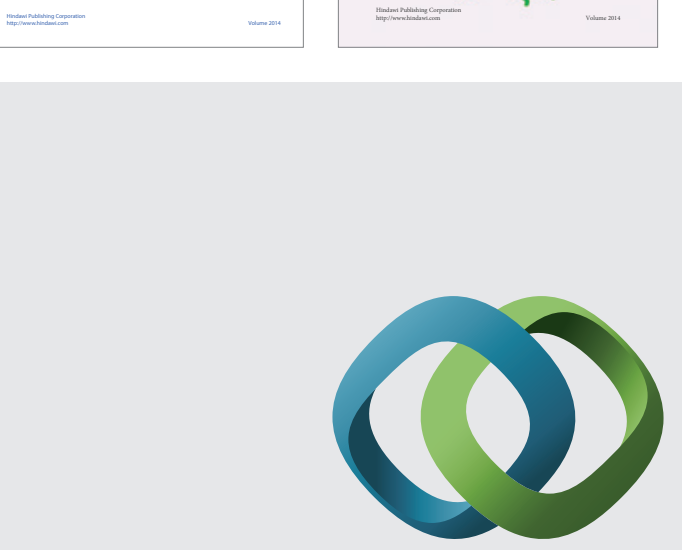

\section{Hindawi}

Submit your manuscripts at

http://www.hindawi.com
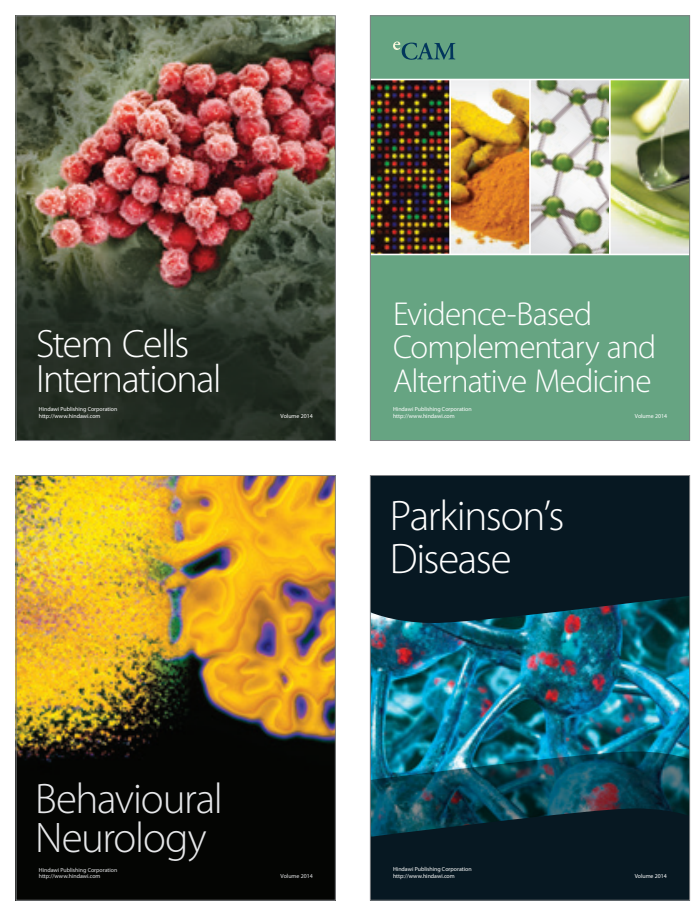

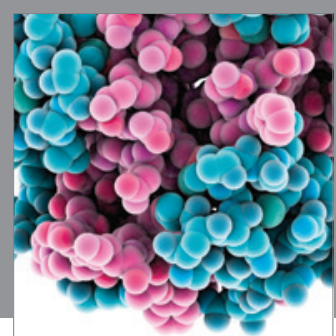

Journal of
Diabetes Research

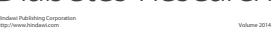

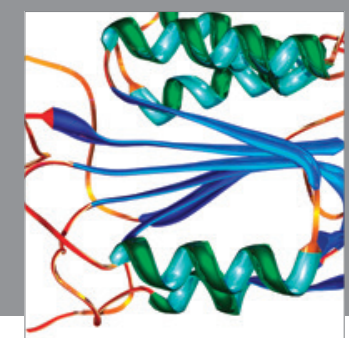

Disease Markers
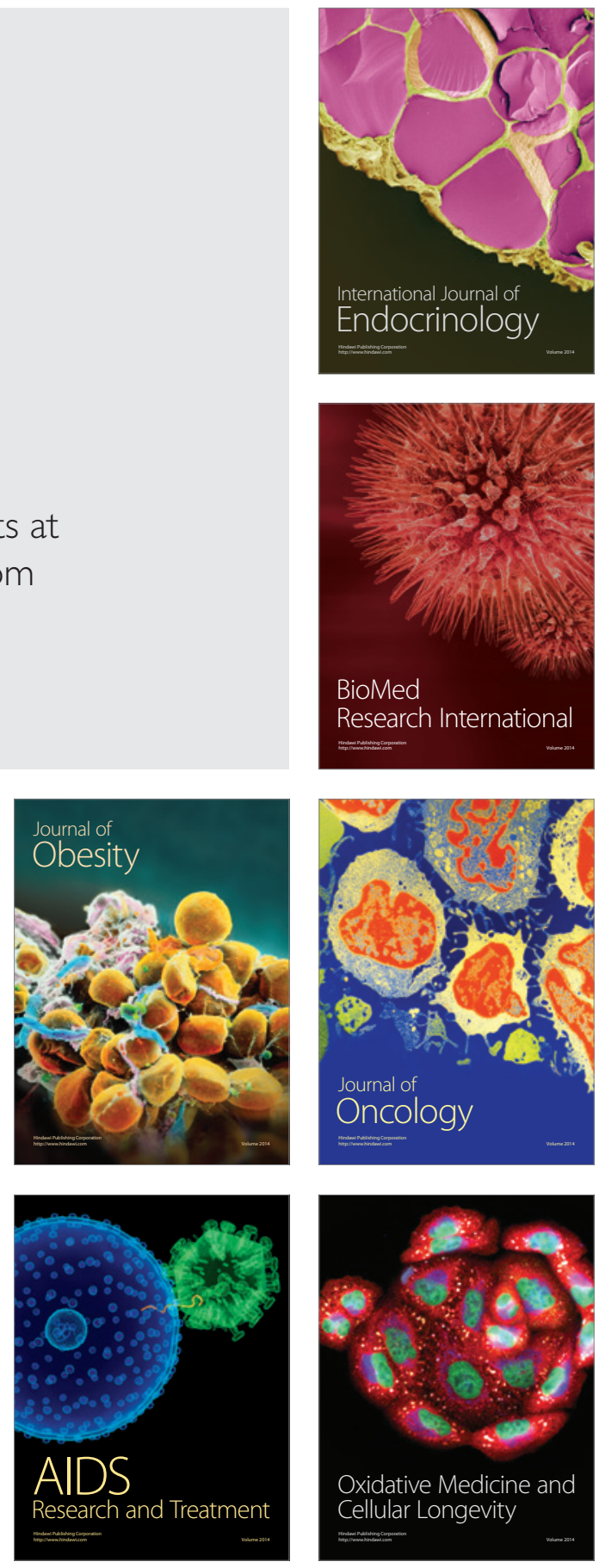